\title{
Interactions of Market Horticultural Productivity on Climate and Weather Variations in the Northern Senatorial District of Cross River State, Nigeria
}

\author{
Eneji V. C. O. ${ }^{1}$, Ogar D. A. ${ }^{2}$, Omoogun C. A. ${ }^{3}$, Dunnamah A. Y. ${ }^{4}$, Ojikpong C. ${ }^{5} \&$ Ekpo C. ${ }^{6}$ \\ ${ }^{1}$ Department of Geography (Rural Development), School of Environmental Sciences, Federal University of \\ Technology, Yola, Nigeria \\ ${ }^{2}$ Department of Forestry and Wildlife Resources Management, University of Calabar, Nigeria \\ ${ }^{3}$ Department of Curriculum and Teaching, University of Calabar, Nigeria \\ ${ }^{4}$ Department of Economics, Ahmadu Bello University, Zaria, Nigeria \\ ${ }^{5}$ Department of Geography, College of Education, Hong, Adamawa State, Nigeria \\ ${ }^{6}$ Science and Environmental Education, University of Abuja, Nigeria \\ Correspondence: Eneji V. C. O., Department of Geography (Rural Development), School of Environmental \\ Sciences, Federal University of Technology, Yola, Nigeria. Tel: 234-808-504-0272. E-mail: \\ vcogareneji@yahoo.com
}

Received: July 23, 2012 Accepted: April 10, 2013 Online Published: April 16, 2013

doi:10.5539/enrr.v3n3p1

URL: http://dx.doi.org/10.5539/enrr.v3n3p1

\begin{abstract}
Various definitions have severally been adduced to poverty as the major cause of most environmental problems ranging from resources depletion, species extinction, deforestation, erosion etc. Majorly man's activities on the biosphere has tended to impact negatively on the environment, this activities are primarily carried out to sustain man's existence on the planet earth. These activities include faulty farming practices, indiscriminate use of agrochemicals including fertilizers for agricultural purposes, urbanization and industrial development. This research took a cursory look at the activities of rural farmers cultivating vegetables and other market gardening activities in order to sustain themselves during dry season as safety net for shortfalls in family income and food. These activities are done along watershed and this involves clearing, tilling, use of inorganic manure, herbicides amongst others. Researches including this have shown that these farming practices are detrimental to the ecosystem and have contributed greatly to affecting the ecological balance of the supportive ecosystem. This research therefore set out to assess how these dry seasons agriculture carried out within the study areas has affected the environment vis a vis climate and weather variation. The research adopted field experiment where data were collected twice per year for a period of five years from the farm site and the local meteorological station at Ogoja. The authors used bar graphs to present data from the field. Using rainfall, temperature and soil moisture content data for five years, the authors gathered that this farming activities has impacted negatively on the environment affecting both weather and climate variation. It was also observed by the researchers that though the data for five years was very minimal for any positive generalization, but findings shows that there were some noticeable changes attributed to these activities. It was recommended that hand dug well or boreholes should be used as sources of water supply to avoid destruction of the watershed. It was also suggested that farm yard manure should be used instead of the inorganic manure that has become detrimental of late to both the environment and human health.
\end{abstract}

Keywords: watershed destruction, climate variation, food security, environmental degradation

\section{Introduction}

The economic and social main stay of most communities in the world today is agriculture. Agriculture, be it mechanized or peasant farming accounts for more than half of the world population's source of food and income. Agricultural production accounts for less than five percent of the gross world product not minding the size of its workforce and its contribution to society's survival (an aggregate of all gross domestic products) (Gordon et al., 2007). Poverty has been attributed as the root cause of most environmental problems in our world today. Because 
poor people are always faced with the problems of meeting their daily needs; food, shelter, health and other financial requirement they are forced to fall back to the land for their daily survival not minding the impacts of their action on the environment. The only place they can turn to for their survival is the land or the environment where they look at the resources within as their ancestral inheritance. They see these common pool resources as their last reserve where they can always fall back to for complimenting their sources of livelihoods. The pressure of the activities of man on the environment has increasingly affected the ecological system and its resources. This has also affected biodiversity and other species within the ecosystem. Man's activities on the environment has altered the ecological balance and functioning of the entire ecosystem. This interaction is due to the energy flow or the thermodynamic interactions taking place within the ecosystem. The sum total of these effects is specie extinction including specie loss, endangerment, disappearance and ecological problems like shortage in rainfall, climate change, flooding, increased heat, and fertility loss and food insecurity.

Chrispeels and Sadava (1994) saw the action of man in the environment as acting without thinking about the environment and the future generations. Pretty et al. (2000) observed that man has so impacted on the environment that he does not even think well about the influence of his activities on the environment. While Darlong (2004) observed that poverty is the reason behind man's unquenching action to compulsorily satisfy his basic needs. According to Maslow (1963), these needs are arranged in an ascending order, and once a particular need at the lower order is met, the next need on this hierarchy of human needs surfaces automatically. Maslow, (1963) listed human basic needs to include, physiological needs (food, shelter, clothing etc), safety need (security, consciousness and identification among a crowd of people), love (acceptance, love and belonging), self esteem (human dignity and respect, self integrity, self pride and honor) and self actualization (the sense of fulfillment and arrival in the social strata in any society, class formation and attainment).

Sol (2003) avers that most causes of environmental problems are caused by habitat decimation and destruction, urbanization, pollution and natural disaster. Eneji et al. (2009a) included faulty agricultural practices as another cause of environmental problems. In their submission, they looked at the major problems of the environment to include deforestation for whatever reason, agriculture, urbanization, infrastructural development, poor agricultural practices (peasant agriculture, rotational bush fallowing, shifting cultivation, mechanized agriculture with the concomitant indiscriminate and unregulated use of agrochemicals, herbicides, insecticides, pesticides, inorganic fertilizer), habitat decimation, pollution from both domestic, industrial and commercial production and consumption processes. Other forms of waste, from industrial, domestic and commercial activities all contributes in no small way to environmental degradation (Expedito et al., 1996; Alakali et al., 2006; Borger, 2008).

The activities of these rural farmers/horticulturalists in the study area in an attempt to increase their sources of income and improve their livelihoods have contributed in greater dimension to destroy the ecosystem leading to the variation of the climatic/weather conditions of the area. In these study areas, agriculture is still at the traditional level, with the use of local farm implements like hoe and cutlasses for clearing and cultivating land, bush burning is another method of clearing land for farming activities. In some communities, stumping is also done where there appear to have too many shrubs on the farmland. Besides the major staple food crops cultivated for family consumptions like yams, cassava, maize , banana, guinea corn, millet, long beans, potato, rice etc, most women and young people have resorted to cultivate rice, and some vegetables during the dry season to improve their income basically and to contribute occasionally to their feeding. In villages like Ugboro, Ukpah, Otukpuru, Akurinyi, Ukpada, Abuochiche, Beten, Nyanya, Gabu, Igoli and a pocket of other communities, they now cultivate rice twice on the same portion of land per year. The idea in itself is to guarantee food sufficiency and food security and also to increase their income, but the methods of cultivation with low agricultural inputs rather depending on the natural fertility of the soil for better yield has become worrisome of late. Young women and men now cultivate vegetables like pumpkin (Telfairia occidentalis hook) green vegetables (Amaranthus spinosus), okra (Hibiscus esculantus), ginger (Zingiber offinaciale), waterleaf (Talinum triangulere), curry, pepper, and other such annual short live crops along watershed. According to Akinkugbe, (2007) this type of market horticultural practices and short period agricultural activities destroys the ecosystem and the ecobalance leading to leaching of fertile soil, destruction of watershed and destruction of soil fertility fixing microorganism. The choice of cultivating along watershed is to have access to water close to their farm where they could do manual irrigation of the crops directly from the streams or rivers. A watershed is any area drain by any body of water or a stream. This therefore means that as they engage in this type of dry season agriculture/ horticulture, their choice of land is along watercourses, which are the main watershed of the area (Eneji, 2006). During land preparation, they deforest the land with machetes and cutlasses; burn the grasses, then till the land using local farm implements (hoe and shovels). In the process of clearing and cultivating, they destroy the watershed. The result of these unwholesome farming activities is the destruction of environment and the climatic variations in 
global and local climate regimes of the communities (Borger, 2008). This activities of local market gardeners in the area has contributed in time past to destroying the watershed and exposing the top soil to direct effect of solar radiation and heat. The burning of these grasses has also generated a lot of heat on the soil, thereby killing some microorganisms responsible for soil fertility replenishment and other nutrient recycling in the farm site under study (Silveira et al., 1996; Akatugba, 2004; Pretty, 2000; Field, 1997; World Bank, 1995).

In a research by Ojugo (2009) on the effect of tillage method on soil microclimate and yield of fluted pumpkin (Telfairia occidentalis hook. f), looking at the effect of tillage on ground cover, he observed that ground cover influenced surface runoff, the dynamics of soil moisture, and played an important role in soil and water conservation. Baker et al. (2000) observed that ground cover mainly refers to living land surface cover, non-decomposed and semi-decomposed plant litters mulched on the soil surface, once these ground cover are destroyed, the living part of the earth has been destroyed (Yaqub, 2007). In this study, they used Paspalum notatum and its litter to study the effects of ground cover on distribution of soil moisture along a slope.

The practice of slash and burn agricultural system has both negative and positive consequences. The positive consequences, which local farmers always capitalize on, is that the fire burns off all insects and crop pest which would have ordinarily affected or attacked their crops (Pretty, 1994). Other usefulness of burning farm sites includes easy way of discarding the thick grasses and packing them from the farmland. Scientifically, the major positive impact of bush burning is that in an acidic soil, the ash from the burnt grasses is very rich in alkalinity, so it helps to reduce the soil acidity hence allowing the neutralization of the acidic soil content and improving crop productivity. However, the point always forgotten even at that is that how did they test the soil to ascertain whether the soil is basic or acidic in nature to know whether it needs neutralization or improvement on the soil acidity (Pretty, 1994). Negative effect of bush burning for agricultural purpose by our local and peasant farmers is the killing of soil micro organism responsible for soil fertility improvement and decomposition of leaf litters and other living things amongst which are nitrosomonas, (nitrogen fixing bacterial in the stem and leave nodules of rhizomes and cover crops, azocotbacter, fungus, bacteria). Another is the reduction of soil water or moisture content by evaporation as a result of the heat from the burning. Most often when this type of crop production is practiced, the local farmers use all kinds of inorganic fertilizers to boast their crop productivity especially market horticulture. Synthetic nitrogen, along with mined rock phosphate, pesticides and herbicides has greatly increased crop yields in the study area (Suman \& Chakesang, 2008). In these areas of study, inorganic chemical fertilizers like NPK 15:15:15, NPK 20:10:10, NPK 12:12:17:2, ammonium nitrates popularly known as urea and herbicides are ignorantly applied to the soil and water without knowing the chemical composition and implication for both the soil, water, animal and humans that may consume such crops or vegetables (Schneider, 1989; Eborge, 2002; FAO, 2008). The use of obnoxious chemical to kill grass and bushes around, some of these herbicides are those that have been disbanded from usage in other part of the world, but are now being used in Nigeria (Brady \& Weil, 2002; Schneider, 1989; Gordon et al., 2007).

Micro climatic conditions and variations in ecological systems within the region have generated very complex weather and climatic conditions. To analyze the perceptions of communities practicing these horticultural systems in relation to their experience with eco-climate change, five unique sites practicing this traditional market gardening were selected. The mean annual rainfall varies from $2000-4000 \mathrm{~mm}$ with most rainfall concentrated from May to September.

\subsection{Some Market Horticultural Practices}

Vegetation clearing: (Slash and burn): the clearing of the topsoil's vegetation and the setting of fire to burn the grasses to enable land cultivation is slash and burn. This is also called land clearing and burning. This process exposes the top soil to direct solar radiation and thermal heat, while the burning also kills soil microorganism, which are responsible for the fixation of soil nutrient, recycling and decomposition of dead materials (Azotobacter and nitrosomonas and denitrifying bacteria).

Land preparation or cultivation (also call soil tillage): The ploughing of the top soil in preparation for planting or for the addition of nutrient, herbicides and pesticides. Land cultivation varies in intensity from zero to complete traditional tilling. Though this method may improve crop productivity through the warming of the soil, introduction of fertilizer and through weed and pest control, but the unintended effect leads to rendering the soil more exposed to ecological and climatic conditions such as erosion, it catalyses the decay or decomposition of soil organic matter releasing $\mathrm{CO}_{2}$, and reduces the abundance and diversity of soil organisms while also increasing the average temperature of the area (Brown, 2008).

Nutrient/fertility management: This is the process of inputting crop nutrient or soil fertility to improved crop productivity. Fertility inputs or nutrient management has to do with the introduction of either organic or 
inorganic manure/fertilizers, farmyard or compost and phosphate minerals from rocks to boast crop yield. Manure is applied by spreading either dry or in liquid form on cropland or farm sites where crops and vegetables are cultivated. The commonest type of manure used by these farmers are the inorganic compound manure like NPK and Urea, though in some cases organic manure like farmyard manure, animal dung's and composting are also used. In this type of agriculture, other forms of soil fertility management like rotational bush fallowing and shifting cultivation are rarely practiced.

Soil water management: This is the practice of improvising water for crop growth. Attempting to manage soil moisture content and water by manually irrigating the land from the river or stream where such gardening is done along watershed involves altering the water condition of the watershed. This practice is done during the dry season where market gardening is carried out. The practice includes mulching, irrigation and regular watering of crops especially vegetables (Suman \& Chakesang, 2008)

The study was carried out to assess how these agricultural practices of dry season farming can affect the climatic and weather condition of the study area and the larger community as a whole. The study also seeks to establish if the farming practice can affect local climate modification and environmental change.

\section{Methodology}

This study was located within the northern senatorial district of Cross River State; the Northern Senatorial District of Cross River State is made up of five local government areas: Ogoja, Yala, Bekwarra, Obudu and Obanlikwu Local government areas of Cross River State, Nigeria. However, the study was rather concentrated in Bekwarra and Ogoja local government areas. The specific study sites are located at Kwarikwata swamp in Igoli, Ogoja local government area, Illa stream in Gakem village, Unwaodaa stream and Uduo River, in Otukpuru village, Junction swamp in Abuochiche, Ityem River in Ukpah and Ugboro in Bekwarra local government area. These villages and farm sites for market horticultural productivity (market gardening) were purposefully selected because they have been engaged in market gardening activities over the years. They cultivate dry season/short period vegetables like fluted pumpkin (Telfairia occidentalis Hook. F), green vegetables (Amarantus spinosus), waterleaf (Talinum triangulere), maize (Zea mays), okra (Habiscus esculantus), scent leaves, (Cymbopogon Winterianus, Geranium Pelargonium), garden egg (Solanu melongena var., esculentum, Solanum integrifolium), pepper (Capsicum annuum) curry leaves (Murraya koenigii), onions (Allium, stellatum, Alum selpa), ginger (Zingiber officinale Roscoe) among others. The study area according to the 2006 national population census has an aggregate combine population of more than 350,000 persons; with a gender ratio of 1: 3 (male: female ratio), their major occupation is predominantly peasant farming for feeding their immediate families with very little for market. Peasant farming is the predominant occupation of the people, a reasonable percentage of the population are civil/public servants and businesspersons. The area is bounded by Obudu and Boki local government areas in the East, while in the North, it is bounded by Vandeikya of Benue state, in the West, it s bounded by Okuku and Yache in Yala local government area, while in the South the area is bounded by Ikom all in Cross River State, Nigeria.

The study was carried out under a five years period. The authors used both Action and experimental research design. Using participatory research method involving semi-structured interviews (SSI) on focal groups of farmers, data was generated on agricultural land use pattern in these study areas. First, the authors designed a key informant interview and administered to the people involved in the cultivation of market horticulture, this was to enable us ascertain if there has been any noticeable change or variation in the weather and climatic condition of the area. These changes we tried to attribute to the horticultural production activities, which they have carried out over the years. The authors also administered interview and questionnaire to some people living around the areas where these farming practices are being carried out. This is to identify if there are changes in water, reduction in rainfall, river dry up, forest depletion, watershed destruction, and increase in temperature among other variables conceived to be associated with these farming practices. A total of 100 persons were interviewed and discussed with informally. During this five years period, the researchers collected soil samples from the farming sites during the farming season and exposed the soil samples to two types of treatments. We weighed the soil samples immediately there were collected from the farm sites, then expose the sample to the sun for some period and then weigh again to check for weight loss because of evaporation. We also heat some of the soil samples using a Bunsen burner in the laboratory to determine the rate of evaporation and to ascertain if any soil moisture is lost during burning and exposure to heat from direct sun light since the vegetation cover is regularly removed during the dry season. We took the temperature of the farm sites for both dry and rainy season for a period of five years using stationed thermometers and the amount of rainfall within the study period using a graduated rain gauge. During the same period of study, we also collected data from the meteorological station at Ogoja for temperature and rainfall. The yearly average for temperature and rainfall and also the average for every six months dividing 
the seasons into when they cultivate these market crops and when they don't, though we were not oblivion of the fact that temperature increases during dry season. We interviewed residents who have lived in the area for onwards of ten years and above to compare what they see now in the area as compared to what they had seen before these farming activities became prominent in the area. Results from the field sample study are as shown in the tables below.

\section{Results}

From Figure 1 below, there is a marked increase in temperature as a result of the farming activities practiced in the area and this has contributed to the rise in temperature over the study.

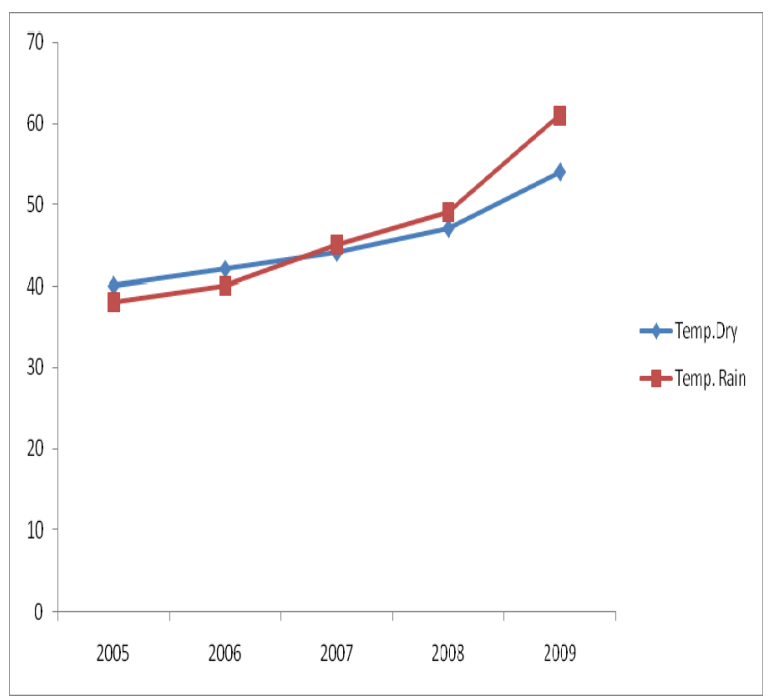

Figure 1. Temperature variations between dry and rainy season during the study period $\left({ }^{\circ} \mathrm{C}\right)$

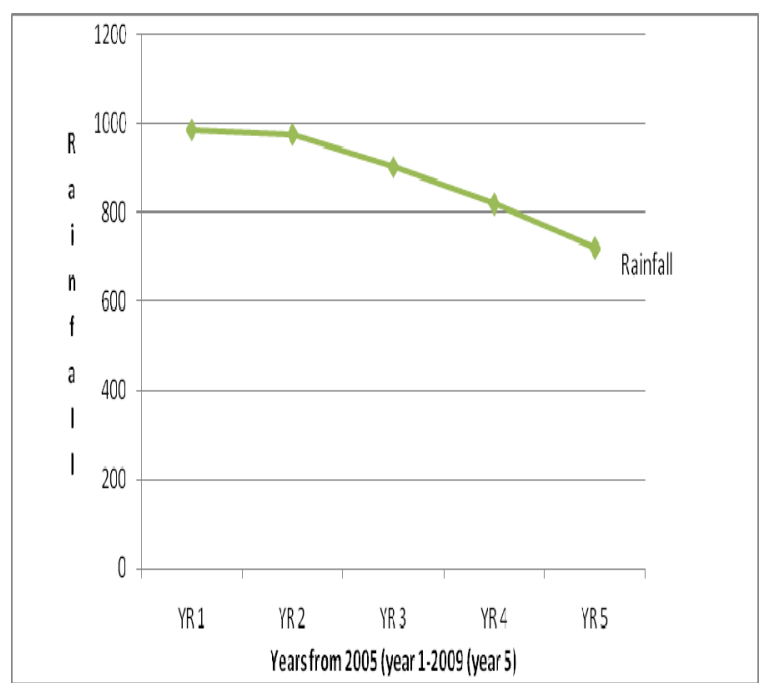

Figure 2. Annual rainfall variation within the study periods in the farm sites

There is thus a steady increase in the mean annual temperature figures over the years increasing from 2005 at $43.4{ }^{\circ} \mathrm{C}$ to $54.8^{\circ} \mathrm{C}$ in 2009 during the dry season when they engage in market gardening, while there is also an increase in the mean annual temperature in the study areas during the rainy season from $40.7^{\circ} \mathrm{C}$ in 2005 to 50.2 ${ }^{\circ} \mathrm{C}$ in 2009. When the variance is calculated within these study periods, there is a marked increase in temperature. From this analysis, it therefore means that the farming activities carried out during this period contribute to a change in temperature within the area under study.

Figure 2 also shows that there is reasonable reduction in rainfall due to deforestation, bush burning and direct exposure of the soil to heat from the sun. This is because of the land clearing and subsequent destruction of the watershed along the watercourses where they cultivate these farms during dry season. From the graph below, the rainfall values shows a reduction of $-264.8 \mathrm{~cm}^{3}$ within the study period. This is so because the soil moisture content evaporates at a rate higher than the normal. The second reason is that the watersheds are usually destroyed leading to the reduction in rainfall volume and frequency. This farming activity therefore has significant impact on the rainfall pattern and frequency.

From Figure 2 above, it is observed that there is a reduction in the soil moisture content, this shows a marked difference in temperature which was attributed to the exposure of the soil to direct heat from bush burning and solar radiation as a result of deforestation over a period of 5 years. The mean variance in temperature between the years 2005 and 2009 shows an increase temperature of $17.2{ }^{\circ} \mathrm{C}$, this shows an annual increment of $3.4{ }^{\circ} \mathrm{C}$.

The result is that there is an increment in temperature and a reduction in rainfall and soil moisture content in the area under study. From our personal interviews and observation, the main reason for people engaging in these farming activities is to improve their income and supplementing their food during times of want. The people also observed that there is well-established change in the environment, especially as the amount of heat observed these days is quite different and higher than what was the case some years ago. The respondents also complaint about the amount of rainfall which has also reduced as compared to what use to be the case in these areas. They attributed the cause of all these to bush burning and deforestation as being carried out in the area. Some informed 
people called the observed problem desertification.

Result from the KII also shows that people living within the study areas over the years have agreed to have noticed some changes, according to them, these changes may not only be due to the existence of the these farming practices only, but also because of the prevalent scarcity of water which force people to turn to the forest for this type of agriculture. Another reason adduced for this change in the forest condition was that cattle Fulani's move with their cattle into the forested areas of the zone, while this was never the case. Even at that some were blunt in their position that it is true that the gardening system is contributing in no small way to the feeding of the population, but the environmental cost associated with this farming system is too much for the community to bear.

\section{Discussion of Findings}

From the graphs and tables, the results shows that there is a marked difference in temperature, rainfall and soil moisture content and above all, observed changes in environmental and climatic conditions in the study areas. It was clear from our discussions that traditional practices in agriculture are overloaded with eco-climatic problems ranging from siltation, soil moisture content loss, reduction in rainfall, increase in temperature, increase in atmospheric carbon, soil fertility loss and biodiversity depletion and in some cases, extinctions. Because the practice of this farming pattern and system is to provide for immediate food shortage and to also carter for the urgent financial needs of those who become engaged in market gardening. This is further buttressed by the findings of Oamen (2004). This local innovation requires minimum supply of water and is practiced after the rainfall when water becomes scarce. They now depend on water from the streams and rivers, and farming along watershed, hence the destruction of watershed reducing rainfall in the farm area. Due to reduced rainfall and moisture in the soil, most land is becoming desertified. This phenomenon is rated as one of the major ten ecological problems in recent times. Desertification does adversely affect the socioeconomic development of any society. Desertification does not only cause serious harm to ecosystem, but also has adverse effects on many aspects of socioeconomic and cultural development of the entire region (World Bank, 1995). Some of the problems associated with desertification as a result of reduced moisture availability in the soil includes: Reduced soil quality and arable land size, reducing the quality of soil for crop productivity. Soil desertification from reduced moisture content and rainfall diminished biodiversity and bio-productivity. In this case, desertification has extremely serious ecological consequences. With this type of farming activities, it leads to soil moisture content loss which causes high soil and water loss, with some soil deposition in rivers and lakes; this worsens the whole ecological environment (World Bank, 1995). This also increases poverty and reduction of economic benefits. Because desertification destroys land and water balance, it also aggravates poverty.

The result from the field was further buttressed by the observation of residents within the study area during the Key informant interview. Even though most of those interviewed were illiterate, they agreed that they have noticed some changes in the forest conditions and also on the intensity of heat generated from the sun and the volume of rainfall which has decreased in recent times considerably. The deterioration of the ecological environment aggravates the contradiction between man and nature, making it difficult to establish a harmonious relationship among society, nature and ecological civilization (Yu et al., 2002; Brown, 2008). The activities carried out by these farmers' causes serious threats to the eco-climatic regime of the local people and this contribute in no small way in modifying the local climate of the environment. Some of the ecological implication of market horticulture as practiced by these people include but not limited to these listed here. Agriculture imposes external costs upon society through pesticides, nutrient runoff, excessive water usage, and assorted other problems.

Land transformation, the use of land to yield goods and services, is the most substantial way humans alter the Earth's ecosystems, and is considered the driving force in the loss of biodiversity. Estimates of the amount of land transformed by humans vary from 39-50\%. Land degradation, the long-term decline in ecosystem function and productivity, is estimated to be occurring on $24 \%$ of land worldwide, with cropland over represented. The UN-FAO report cites land management as the driving factor behind degradation and reports that 1.5 billion people rely upon the degrading land. Degradation can be deforestation, desertification, soil erosion, mineral depletion, or chemical degradation (acidification and salinization).

Eutrophication, excessive nutrients in aquatic ecosystems resulting in algal blooms and anoxia, leads to fish kills, loss of biodiversity, and renders water unfit for drinking and other industrial uses. Excessive fertilization and manure application to cropland, as well as high livestock stocking densities cause nutrient (mainly nitrogen and phosphorus) runoff and leaching from agricultural land. These nutrients are major nonpoint pollutants contributing to eutrophication of aquatic ecosystems. This finding affirmed conclusions of Arnold (1992) and 
Ogar (2005) who observe respectively that inorganic chemical fertilizers contribute an unintended outcome of over fertilizing water bodies which increases the growth of water hyacinth and also increase the carbon content of the water on the top preventing oxygen from going under for plants and animals to live on, here eutrophication arises.

Climate change can potentially affect agriculture through changes in temperature, rainfall (timing and quantity), $\mathrm{CO}_{2}$, solar radiation and the interaction of these elements.

It has been established beyond all reasonable doubt that the gardening activities as carried out by these local farmers have contributed in no small way to negative modification of local climate and this can also result to climate change, reduction in water supply as a result of watershed destruction, water pollution, eutrophication and species extinction and endangerment, increased atmospheric carbon, temperature increase and reduction in rainfall and salinization of rivers and other water bodies.

\section{Conclusion}

These market horticultural farming activities had shown that they have deleterious effect on the environment and also on human health and wellbeing. The farming system also cause erosion and slope formation along cultivated area and along the water shed where they cultivate the rich forest soil for water availability assurance and fertility. Above all there is the destruction of the watershed that guarantees our steady supply of water, hence most water bodies in the area have completely become shrunken or dried up. Most of the forest areas have been depleted and some places have been completely laid bare as a result of these farming activities of market horticulture. This had led to most land becoming dry and empty, with just minor shrubs here and there in the farmland. This situation of climatic and weather change is noticed within Uduo river and Unwaodaa in Otukpuru, Junction spring in Abuochiche, Illa in Gakem, Ityem in Ukpah and Ugboro and Kwarikwata in Igoli, Ogoja. The case is becoming so critical that it has become a case for concern of late because this practice is detrimental to the environment. These ecosystem disturbances as a result of these market horticultural productivities have also been confirmed by the researches of other scholars like the Millennium Ecosystem Assessment. These complex trade-offs between increased agricultural production and declines in other ecosystem services as caused by agricultural changes to the hydrological cycle have been reviewed by the Millennium Ecosystem Assessment and the Comprehensive Assessment of Water Management in Agriculture Comprehensive Assessment of Water Management in Agriculture, Water for Food, Water for Life: A Comprehensive Assessment of Water Management in Agriculture, Earthscan Publications (2007). This review research revealed that knowledge of these trade-offs is prolific and increasing, this also shows that we lack an integrated understanding of how agricultural modifications of the hydrological cycle regulate the prevalence and severity of weather and eco-climatic change in ecosystems (Gordon et al., 2007).

In view of the foregoing, it is clear that the farming activities carried out by these groups of farmers have potentially contributed in no small way to environmental deterioration and degradation in the area under study. It is necessary to mention here that though the time frame of five years was scientifically too short to record any reasonable climate change, but with careful observation and analysis followed by independent studies, we drew the conclusion that there is observed local climate modification and change in this area.

\section{Recommendations}

From the findings in the field, we came up with the following suggestions:

- There should be the introduction of the use of water from a reservoir or hand dug well to replace farming along water course.

- Such farms should be cultivated away from watershed and watercourses.

- The use of inorganic artificial fertilizer should be replaced with the use of organic manure like composting and farmyard manure from the leaf litters and the grasses removed from land clearance in the farm.

- Government should design a well articulated poverty reduction strategy that will reduce undue pressure on the environment.

- Proper laws should be made regarding the importation, use and control of most of the agrochemicals which have been bounded out of the country and Nigerian and most African countries are now found as a dumping ground for such chemicals which researches have found to contribute to more than $42 \%$ of cancer in Nigeria.

- Agricultural extension agents should also be sent to these rural communities to help in articulating and providing services on modern horticultural production methods which are ecologically friendly. 


\section{References}

Akatugba, C. V. D. (2004). Evaluation of the utilization of common leafy vegetables in Southern Nigeria. Journal of Vegetables Studies, 2(1), 23-28.

Akinkugbe, J. H. (2007). The production processes and marketing of vegetables in selected urban centres in Edo and Delta States. Journal of Business Management, 10(1), 14-20.

Alakali, S. J., Ariahu, C. C., \& Mkpa, A. (2006). Kinetics of osmotic dehydration of mango slabs. J. Food Processing and Preservation, 30(5), 597-607. http://dx.doi.org/10.1111/j.1745-4549.2006.00080.x

Arnold, J. E. M. (1992). Production of Forest Product in Agricultural and Common Land Systems: Economic and Policy Issues. In E. Sharma \& Narendra (Eds.), Managing The World's Forest. Iowa: Kendal/Hunt Publishing Company.

Baker, J. B., McKinney, B., \& Hurd, J. (2000) Initial Assessment of Social and Economic Factors Affecting Biodiversity Conservation Efforts in the Forests of the Lower Mekong Ecoregion Complex, IUCN and WWF. Hanoi.

Borger, J. (2008). Feed the world? We are fighting a losing battle, UN admits. The Guardian (London).

Brady, N. C., \& Weil, R. R. (2002). Nitrogen and Sulfur Economy of Soils. Elements of the Nature and Properties of Soils. (pp. 386-421). Pearson Prentice Hall, Upper Saddle River, NJ.

Brown, L. (2008). Global Water Shortages May Lead to Food Shortages-Aquifer Depletion.

Chrispeels, M. J., \& Sadava, D. E. (1994). Farming Systems: Development, Productivity, and Sustainability. Plants, Genes, and Agriculture (pp. 25-57.) in Jones and Bartlett, Boston, MA.

Darlong, D. S., (2004). Effects of mound and no-till on the yield of fluted pumpkin in Northern Nigeria. AgroScience, 3(2), 8-14.

Eborge, E. O. D. (2002). Comparative analysis of the growth and yield of yam under mound and ridge tillage. Journal of Agricultural Development, 6(2), 54-66.

Eneji, V. C. O. (2006). Urban and Rural Dwellers Consumption Pattern of Wildlife and its Impact on Biodiversity: The case for Bekwarra and Calabar Urban of Cross River State, Nigeria, Unpublished Degree thesis, University of Calabar, Calabar, Nigeria.

Eneji, V. C. O., Qi, G., Jian, X., Oden, S. N., \& Okpiliya, F. E. (2009). A review of the dynamics of forest resources valuations, issues, arguments and concern. Journal of Agriculture, Biotechnology and Ecology, 2(2), 210-231.

Expedito, T. F., Silveira, M., Shafur, R., \& Backle, M. A. (1996). Osmotic dehydration of pineapple: Kinetics and product quality. Food Research Intl, 29(3-4), 227-233.

Field, B. (1997). Environmental Economics, UK: Earthscan Publication.

Food and Agriculture Organization. (2008). Analysis of farming systems. Rome.

Gordon, G., Peterson, D., \& Bennett, E. M. (2007). Trends in Ecology \& Evolution, 23(4), 211-219.

Maslow, A. (1963). Hierarchy of human needs

Millennium Ecosystem Assessment. (2007). In L. Brown (Ed.), Global Water Shortages May Lead to Food Shortages-Aquifer Depletion.

Oamen, D. E. (2004). The influence of tillage on the yield of intercropped melon and yam in Southern Nigeria. Agro Development and Environmental Protection Monograph, 8, 5-8.

Odjugo, P. A. O. (2007). The effects of tillage systems and mulching on soil microclimate, growth and yield of white yam (Dioscorea rotundata) in Midwestern Nigeria. Journal of Food, Agriculture and Environment, 5(2), 164-169.

Ogar, E. A. (2005). Effects of fertilizer rates and cutting frequency on the marketable vegetable and pod yields in fluted pumpkin in south Eastern Nigeria. AgroScience, 4(1), 66-69.

Pretty, J. N. (1994). Alternative systems of inquiry for a sustainable agriculture. IDS Bulletin, 25(2), 37-49. http://dx.doi.org/10.1111/j.1759-5436.1994.mp25002004.x

Pretty, J. N. (2000). An assessment of the total external costs of UK agriculture. Agricultural Systems, 65(2), 113-136. http://dx.doi.org/10.1016/S0308-521X(00)00031-7 
Schneider, K. (1989). Science Academy Recommends Resumption of Natural Farming. The New York Times. Retrieved from September 8 , 1989 , http://www.nytimes.com/1989/09/08/us/science-academy-recommends-resumption-of-natural-farming. html

Silveira, M., Expedito, T. A., Shafhur, R., \& Ken, K. B. (1996). Osmotic dehydration of pineapple: Kinetics of product quality. Food Research Int, 29(414), 227-233. http://dx.doi.org/10.1016/0963-9969(96)00035-X

Sols, S. (2003). Global Environmental Outlook 3. Earth Scan Publications.

Tegtmeier, E. M., \& Duffy, M. (2005). External Costs of Agricultural Production in the United States. The Earthscan Reader in Sustainable Agriculture. Retrieved from http://www.organicvalley.coop/fileadmin/pdf/ag_costs_IJAS2004.pdf.

World Bank. (1995). Overcoming Agricultural Water Pollution in the European Union.

Yaqub, A. A. (2007). The effects of leaves harvest on the yield of pumpkin fruits in the middle belt of Nigeria. Journal of Environment and Agriculture, 5(1), 78-86.

Yu, W. (2002). In L. R. Brown (Ed.). Global Water Shortages May Lead to Food Shortages-Aquifer Depletion. 